\title{
नेपालको भूसामरिक हैसियत : विगत र वर्तमान
}

\section{भमकप्रसाद शर्मा}

\section{लेखसार}

प्रस्तुत लेखमा नेपालको भूसामरिक हैसियत र त्यसको व्यवस्थापन पक्षलाई ऐतिहासिक परिप्रेक्ष्यबाट लेखाजोखा गर्दे वर्तमानमा विश्वमा आफ्नो भूसामरिक हैसियतबाट लाभान्वित हुन नेपालले के कस्ता रणनीति अवलम्वन गर्नु फलदायक हुन्छ भन्ने कुराको विश्लेषण गर्ने काम भएको छ। यसमा विश्लेषणात्मक र विवेचनात्मक पद्धतिको प्रयोग गरिएको छ। कुनै देशको भौगोलिक अवस्थितिले त्यस देशको आत्मरक्षा, कूटनीति, परराष्ट्र नीति, राष्ट निर्माण, राष्टियता निर्माण, संस्कृति र सभ्यता निर्माण तथा आर्थिक विकासमा राख्ने तादात्म्यता नै भूसामरिक हैसियत हो। अनुकूल भूसामरिक हैसियत भएको कारणले नेपाल अनादिकालदेखि आफ्नो भौगोलिक अखण्डता र स्वाधीनताको रक्षा गर्न समर्थ भएको छ। इतिहासको कालखण्डमा समयसमयमा नेपालमा हुने गरेका दर्जनौं वाह्य आक्रमणहरुलाई नेपालले अनुकूल भूसामरिकताबाट आर्जित वीरता र रणकौशलताको उपयोग गरेर विफल बनाइदियो। आर्य, खस, मंगोल, द्रविढ लगायतका समुदायहरु भएको मिश्रित समाज भएर पानि सबै समुदायले यहांको भूसामरिकतालाई आत्मसात् गरी आपसी सद्भावना र सामन्जस्यपूर्ण मौलिक संस्कृतिको विकास गरेकाले नेपालीपनको आत्मीय भावना भएको राष्ट्रियता निर्माण भई सुदृढ भएको छ। चीन र भारत दुई ठूला राष्टका बिचको अवस्थितिले गर्दा नेपालको भूसामरिक हैसियतले ती
दुबैको सुरक्षा संबेदनशीलतासंग पनि सरोकार राख्ने भएकाले उनीहरु नेपालप्रति भूसामरिक अभिरुची राख्ने गर्दछन्। तसर्थ उनीहरुलाई सुरक्षाको प्रत्याभूति दिंदै मित्रतालाई सुदृढ बनाई विकास र आपसी सहयोगमा सहकार्य गर्नु समयको माग रहेको छ। छिमेकीको अलावा अन्य मुलुकहरुसंग पनि असंलग्नता र पन्चशीलको सिद्धान्तको अनुसरण गर्दे मैत्रीसम्बन्ध कायम गरी अन्तरराष्ट्रिय सहयोग र सहकार्य जारी राख्तुपई । नेपाल फरक-फरक राजनैतिक प्रणाली भएका दुई ठूला मुलुकको बिचमा रहेकाले ती मुलुकहरुले राख्ने राजनैतिक चासोबाट केही न केही प्रभावित हुने सम्भावना रहनाका साथै नेपालको अनुकूल भूसामरिक हैसियत भएक कारणले कतिपय शक्ति राष्ट्रहरूले यसलाई आफ्नो स्वार्थका लागि प्रयोग गर्न सकिन्छ कि भन्ने अभिलाषा राख्ने सम्भावना पनि रहन्छ। तथापि नेपालीहरूको सामरिक स्वावलम्बन, देशभक्ति अनि राष्ट्रिय अखण्डतालाई प्राणभन्दा प्यारो मान्ने भावनाका कारणले नेपालमा परचक्रीहरूले नकारात्मक गतिविधिका लागि कुनै पनि स्थान पाएका छैनन् र पाउनु पनि हुँदैन। विगतमा भूसामरिक हैसियतलाई युद्ध र प्रतिरक्षासँग मात्र जोडेर हेर्ने गरिएकोमा अबको वर्तमान विश्वमा युद्धको कुनै औचित्य नरहेकाले विकास र समृद्धिका लागि सहकार्य गर्न भूसामरिक हैसियतको उपयोग गर्नु नितान्त आवश्यक छ। यातायातको विस्तार, प्रचुर जलस्रोत र जलविद्युत्को व्यापक परिचालन, पर्यटन प्रवर्द्धन जस्ता कुराहरु हाम्रा उच्च 
प्राथमिकताका विषय हुन्। यसका लागि नेपालले दुवै छिमेकी मुलुकहरुसाँग सम्यक कूटनैतिक सुसम्बन्ध, छिमेकी मित्रराष्ट्रहरूको भसामरिक अभिरुचिलाई कुटनैतिक र सन्तुलित सम्बोधन, चीनले ल्याएको बी आर आई अवधारणाको अवलम्बन, अमेरिकासँग सम्पन्न भएको एम सी सी सम्कौताको कार्यान्वयन समेतका माध्यमबाट नेपालले आफनो भसामरिक हैसियतलाई विकास, समद्धि र अन्तर्राष्टिय भाइचाराका लागि मात्र प्रयोग गर्नु समयको माग रहेको छ।

\section{शब्दकुन्जी}

इण्डोप्यासिफिक रणनीति; एक पाटो एक बाटो (OBOR); एक सडक; कटनीति; खम्पा काण्ड; ट्रान्जिट देश; ट्रान्सिहमालय इकोनोमिक ग्रोथ रिजन; ट्रान्सिहमालयन कोरिडोर; ब्रिक्स् राज्य; बेल्ट; बेल्ट एण्ड रोड इनिसियटिव (BRI); भूसामरिक हैसियत; राष्टिय सुरक्षा; रेशम मार्ग; हिमवत्खण्ड ।

\section{विषय प्रवेश}

प्रस्तुत लेखमा नेपालको भुसामरिक हैसियतलाई विगत र वर्तमान सन्दर्भको धरातलमा राखी विश्लेषण तथा ऐतिहासिक तथ्यका आधारमा विवेचना गर्दे वर्तमानमा विकास र समद्धि हासिल गर्नका लागि यसको व्यवस्थापन कसरी गर्न उचित हुन्छ भन्ने कराको विश्लेषण गरिएको छ। यसमा विश्लेषणात्मक र विवेचनात्मक पद्धति अवलम्वन गरिएको छ।

कुनै देशको भौगोलिक अवस्थिति वा भूबनौटले त्यस देशको राष्ट्रियता, सामाजिक सद्भावना, सभ्यता निर्माण, सुरक्षा व्यवस्था र अन्तर्राष्ट्रिय सम्बन्धमा पर्ने प्रभाव र खेल्ने भूमिका नै भूसामरिक हैसियत हो। भूसामरिक हैसियत अनुकूल वा प्रतिकल दुवै हुनसक्छन्। कोलिनको भनाइ अनुसार एकातिर भौगोलिक तथ्य र अर्कातिर अन्तर्राष्ट्रिय राजनीतिका बिचको अन्तर्सम्बन्धलाई जोड दिने अध्ययन नै भसामरिक हैसियत हो (Colin, 2013, p. 1). कोहेनको भनाइमा अन्तर्राष्ट्रिय राजनीतिक
शक्ति र भौगोलिक अवस्थितिका बिचको सम्बन्ध नै भूसामरिक हैसियत हो (Cohen, 1973, p. 14). आफ्नो भूसामरिक हैसियतलाई दृष्टिगत गरेर कायम गरिएको परराष्ट्र नीति र वैदेशिक सम्बन्ध मात्र दिगो, सार्थक र फलदायक हुन्छ भन्ने कुरा नेपाल लगायत हरेक देशको हकमा लागु हुन्छ। नेपालको सन्दर्भमा अनुकूल भूसामरिक हैसियतको कारणले नै आफ्नो भौगोलिक अखण्डता र स्वाधीनताको रक्षा गर्न समर्थ भएको छ। यो पक्ष अनादिकालदेखि हालसम्म पनि यथावत् छ भन्ने कुरामा कुनै शंड्का छैन ।

\section{भूसामरिक हैसियतबाट संस्कृति र सभ्यता निर्माण}

नेपालको ज्ञात इतिहास पू००० वर्षभन्दा अलिक पुरानो छ। त्यस पहिलेको अवस्था अज्ञात भए पनि अनुकूल भूसामरिक हैसियतकै कारणले अनादिकालदेखि नै यसको भौगोलिक अखण्डता र स्वाधीनता अक्षुण्ण रही आएको कुरामा भने दुई मत छैन। प्राचीनकालमा यो भ-भाग हिमवत्वण्डको रुपमा रहेको थियो। पूर्वमा ब्रह्मपुत्रदेखि पश्चिममा सिन्धुनदीसम्म र उत्तरमा कैलाश मानसरोवर लगायत सम्पर्ण हिमाली क्षेत्रदेखि दक्षिणमा भारतको तलहट्टीसम्मको भ-भागलाई हिमवत्वण्ड भनिएको छ र यसको केन्द्रविन्दु चाहिं नेपाल नै हो (योगी, २०७१, पृ. ६१)। यो भनेको समग्र हिमाली सभ्यताको प्रतिनिधि राष्ट्र समाज र जनसंख्या हो (संग्रौला, २०७६, पृ. ४२९)। विश्वभरका हिन्दूहरुकी आराध्य देवी सीता अनि विश्वभरका वौद्धमार्गीका आराध्य गौतम वुद्धको जन्मस्थल त नेपाल हुंदै हो, यसको अतिरिक्त प्रकृतिको अनुपम भण्डार र अत्यन्तै अनुकूल हावापानीको कारणले गर्दा यहां प्रसिद्ध ऋषिमुनि तथा विद्वानविदुषीहरुले जन्म लिए जसको फलस्वरुप यो भूभाग तपोभूमि, ज्ञानभूमि र ध्यानभूमि बन्नपुग्यो। ध्यान र योगको आविष्कार यहाँबाटै भयो भने आजभन्दा ३००० वर्ष पहिले नै यहाँ चिकित्सा विज्ञानको विकास भइसकेको थियो भन्ने कुराको प्रमाणका रुपमा यहां रचित ‘चरकसंहिता' र ‘सुश्रुतसंहिता' जस्ता ग्रन्थहरुलाई लिन सकिन्छ। वेदव्यास जस्ता महात्रषिले यसै 
ठाउँमा १६ पुराणहरुको रचना गरे। राजा जनकका समकालीन विद्वान् ऋषि यज्ञवल्क्यले 'यज्ञवल्क्यस्मृति' र अष्टावकले ‘अष्टावकगीता' यहाँकै जनकपुरमा रचना गरे । मन्त्रको पनि मन्त्र मानिएको गायत्री मन्त्र कौशिक ऋषिले कोशी किनारमा अवस्थित चतरामा बसेर रचना गरेका थिए। न्युटनले पत्ता लगाएको भनिएको गुरुत्वाकर्षणको सिद्धान्त न्युटन जन्मनुभन्दा पाँच सय वर्षपहिले नै सन् ११५० मा नेपालका भास्कराचार्यले पत्ता लगाएका थिए भन्ने कुरा सन् १२१० मा प्रकाशित उनको पुस्तक सिद्धान्तशिरोमणिबाट पुष्टि हुन्छ। नवग्रहको अवस्थिति र गति, २७ नक्षत्रहरुको पहिचान र मापन, सूर्यग्रहण ₹ चन्द्रग्रहणको निदान यहाँकै खगोलशास्त्रीहरुले गरेका थिए। कालान्तरमा विश्व रझ्मअ्चमा यी निधिहरु ओभेलमा पर्नु दुर्भाग्य हो। किरात मुन्धुमको रचना पूर्वी नेपालकै पहाडी भूभागमा भएको थियो। त्यसैले नेपालमा विकसित भएको सभ्यता नै हिमवत् सभ्यता हो र नेपालको मौलिक पहिचान हो। यस सभ्यतालाई भारतीय सभ्यताको उपभेद मान्नु गलत धारणा हुनजान्छ, किनभने यो नेपालमै विकसित नेपाली सभ्यता हो जुन सनातन वैदिक धर्म, वुद्ध धर्म र किराँत मुन्धुम धर्मको योगबाट बनेको छ र अन्यत्र कतै पनि नपाइने खालको अद्वितीय छ। यसका अतिरिक्त हिमवत् सभ्यताकै उपसभ्यताका रुपमा नेपालभित्र कालान्तरमा विकास भएका $\vartheta$ वटा उपसभ्यताहरू समेत विद्यमान हुनु नेपालको अनुमान विशेषता हो। नेपाल न त धेरै ठूलो देश हो, न त धेरै सानो। विश्वका अन्य मुलुकहरूसँग क्षेत्रफलका आधारमा तुलना गर्ने हो भने सानोमा ४९ औं ऋममा अनि ठूलोमा पनि ४९ औं ऋममा नै पर्दछ। त्यसैले भारतले अनधिकृत रुपमा कव्जा गरिराखेको कालापानी, लिपुलेक र लिम्पियाधुराको क्षेत्रफल समावेश नगर्दा कुल क्षेत्रफल १४७१६१ वर्ग किलोमिटर मात्र भएको देश भएर पनि सीमित भ-भागभित्रै $७$ वटा उपसभ्यताको आविर्भाव र विकास हुनु तथा ती उपसभ्यताहरू अन्य राष्ट्रहरूका भू-भागसम्म फैलनु नेपालको विलक्षणता हो। कोशी उपसभ्यता इन्द्रावती नदीभन्दा पूर्वतिर
विस्तार भई मित्रराष्ट्र भारतको दार्जीलिड, सिक्किम र आसामसम्म, मित्रराष्ट्र भुटान अनि मित्रराष्ट्र वर्माको ऐरावती नदीसम्म फैलिएको छ। वागमती उपसभ्यता काठमाडौं उपत्यका र आसपासमा आविर्भाव र विस्तार भएको छ। त्रिशूली उपसभ्यता त्रिशूली नदीभन्दा पूर्वतिरका भ-भागमा विस्तार भएको छ। गण्डकी उपसभ्यता त्रिशुली नदीभन्दा पश्चिमतर्फ कालीगण्डकी नदीको सेरोफेरोभित्र पर्ने भ-भागमा विस्तार भएको छ। भेरी कर्णाली वा सिंजा उपसभ्यता गण्डकी नदीभन्दा पश्चिमतर्फ भेरी नदीसम्मका भ-भागमा विस्तार भएको छ भने सेती महाकाली उपसभ्यता भेरी नदीभन्दा पश्चिमतर्फका भ-भागस्थित सेती महाकाली नदीको सेरोफेरो लगायत मित्रराष्ट्र भारतका पिथौरागढ, कुमाउ, गढवाल, नैनीताल क्षेत्रभरि विस्तार भएको छ। मिथिला उपसभ्यता तराईको जनकपुरबाट आविर्भाव भई त्यसैसँग जोडिएको मित्रराष्ट्र भारतको निकै ठूलो भ-भागमा विस्तार भएको छ (खड्का, २०७६६६।६)। यी कारणहरूले गर्दा पनि नेपालको सभ्यता मौलिक हो, भारतीय सभ्यताको उपभेद होइन भन्ने तथा प्रमाणित हुन्छ। यसो हुनुमा बाह्य प्रभाव पर्न नदिने खालको नेपालको भूसामरिक हैसियत नै प्रमुख कारक तत्व हो ।

\section{नेपालको भूसामरिक व्यवस्थापनको शैली र राष्ट्र निर्माण}

नेपालले अँगाल्ने गरेको भूसामरिक व्यवस्थापनको शैली विगतदेखि हालसम्म सधैं समयसापेक्ष रुपले परिवर्तनशील हुने गरेको छ, र त्यसैका भरमा राष्ट्र निर्माण भएको छ। नेपालले प्रकृतिकै वरदानको रुपमा अनादिकालदेखि अनुकूल भूसामरिक हैसियत प्राप्त गर्न सकेकै कारणले आफ्नो अस्तित्व अक्षुण्ण रुपमा बचाएर राख्न सकेको छ। सुदूर अतीतमा हिमवत्वण्डको रुपमा परिचित यो भ-भाग दुई ठूला अनि फरक-फरक सांस्कृतिक परिवेश भएका मुलुकहरूबाट परिवेष्टित भएर पनि कहिल्यै कसैको अधीनमा पर्नुपरेन। त्यसो त इतिहासको कालखण्डमा पटक पटक बाह्य आक्रमण नभएका होइनन्, तर सारा आक्रमणहरू विफल भए 
र कसैले पनि यहाँ आधिपत्य जमाउन सकेनन् । अनादिकालदेखि नै नेपालमा परचक्रीहरू टिक्न सकेका छैनन्। यो देश सदा नेपालीहरूकै रही आएको छ। यो हाम्रो गर्न र स्वाभिमानको विषय हो।

नेपालको भूसामरिक व्यवस्थापनको शैलीलाई ऐतिहासिक परिप्रेक्ष्यबाट हेर्ने हो भने यो समयक्रममा फेरिंदै आउने गरेको पाइन्छ। इतिहासको कालखण्डमा हेर्दा प्राचीनकालमा देशको बिच भागमा सैन्यदस्ता राखिन्थयो, मध्यकालमा आएर यो अभ्यासमा परिवर्तन भई विभिन्न उच्चस्थल अर्थात् गडीडाँडाहरूमा र सीमाका हिसावले सम्बेदनशील ठाउँहरूमा किल्ला स्थापना गरी सैन्यदस्ता राख्न थालियो (खरेल, २०७६, पृ. १६६)। अमरगढी, कान्द्राङगढी, बेलकोटगढी, भीमफेदीगढी, सिमरौनगढी, सिन्धुलीगढी आदि ठाउँहरू भसामरिक दृष्टिकोणबाट छनोट गरिएका सामरिक क्षेत्रहरू थिए र बाहय आक्रमण भएका बेला यिनै स्थलहरूबाट प्रतिकार गरी वैरीहरूलाई पराजित गरिन्थ्यो -खरेल, २०७६ पृ. १६६)। नेपाल जस्तो पहाडी मुलुकमा प्रचुर संख्यामा गुफा तथा ओडारहरू हुनु स्वाभाविकै हो। त्यसैले यिनै गुफा तथा ओडारहरूलाई पनि सामरिक स्थलका रुपमा प्रयोग गरी वैरीहरूलाई पराजित गरिन्थ्यो । देशमा बाह्य आक्रमण भयो भने सेनाका साथसाथै जनसाधारणहरू समेत स्वतफर्त रुपमा सेनासँग मिलेर दुस्मनमाथि जाई लागदथे अनि सेना र नागरिकका बिचको यस्तो सहकार्यका अगाडि वैरीको केही चल्दैनथ्यो। के कुरा सत्य हो भने गगनचुम्बी पहाडहरू, घना जङ्गल, गुफा तथा ओडार, परचक्रीले केही मेलोमेसो पाउन नसक्ने खालका गल्छेडा, तीव्र बेगमा बग्ने खोलानाला र नदीहरू सबै कुराहरूले नेपालको भूसामरिक हैसियतलाई अब्बल बनाएका छन् र परिआयोभने दुश्मनका आक्रमणकारी वायुयानसम्मलाई पनि सजिलै गिराउन सक्ने खालको नेपालको भूसामरिक हैसियत छ।

यहाँको विचित्रको भूसामरिक हैसियत अनि सेना र जनसाधारणका बिचको तादात्म्य र सहकार्यको स्थिति बुभेपछि ई. पू. २ू० मा मगधका मौर्य वंशका सम्राट
अशोक जस्ता विजेता 'शासक (Nehru, 1982, p. 61) पनि नेपालका किराती राजा स्थुंकोका सामु टिक्न नसकिने देखी छोरीको विवाह यहाँ गरिदिएर त्यसै फर्किएका थिए (सिंह, २०२६, पृ. ३६)। मौर्य वंशको पतनपछि मगधमा स्थापित गुप्तवंशका राजा समुद्र गुप्तले छिन्नभिन्न भएको मगधलाई पुनः एकीकरण र विस्तार गर्दा पनि नेपालको भूसामरिक हैसियत बुक्केपछि यहाँ आक्रमण गर्ने हिम्मत गरेनन्। कालान्तरमा मगधमा भीषण आक्रमण गर्ने हुणहरूले पनि नेपालमा रणनैतिक पहाडी भूभाग छ भन्ने बुक्केपछि यतातिर दृष्टि लगाएनन्। वि.सं. को तेस्रो वा चौथो दशकतिर लिच्छवी राजा अंशुबर्माका पालामा अभीरहरूले आक्रमण गरेका थिए, तर नराम्ररी हार खाएर फर्किन बाध्य भए (भण्डारी, २०२७, प्. पू६)। द३९ सालतिर काश्मिरका जयापीड विनयादित्य नाम गरेका एक महत्वाकांक्षी राजाले नेपाल हान्ने सुर गरी ठूलो फौज सहित कालीगण्डकी निकट रिडी आइपुगे। तत्कालीन राजा अरमुण्डीले चलाखीसाथ पहिले नै कालीगण्डकी थुनेर पानी जमाइराखेका थिए र नदीमा घुँडासम्म मात्र आउने गरी पानी छाडिदिएका थिए। नदी सानो देखेर शत्रुको फौज कालीगण्डकी तर्न नदीमा पस्नासाथ पहिलेदेखि जमाइराखेको पानी एकैचोटी हवात्तै खोलीदिएपछि फौजको सारा जत्था बाढीमा बगेर बेपत्ता भएको थियो अनि जयापीडलाई अरमुण्डीले बन्दी बनाए (शर्मा, २०३३, प्. १०७)। राजा श्रीनरमल्लदेवका पालामा ११६६ सालमा तिरहुते अर्थात डोयहरूले आक्रमण गरेकामा हार खाई फर्किए। अभय मल्लका पालामा १३०१ र १३०२ सालमा तिरहुते अर्थात डोय राजा रामसिंहले उपत्यकामा आक्रमण गरेका थिए तर दुबैपटक शर्मनाक हार खाई फर्किए (अर्याल, २०४३, पृ. ७४)। राजा अनन्त मल्लका पालामा पनि तिरहुते अर्थात डोयहरूले वि. सं. १३४६ र १३६७ मा दुईपटक उपत्यकामा आक्रमण गरेका थिए तर उनीहरू फेरि शर्मनाक हार खाई फर्किए (अर्याल, २०४३, पृ. ७४)। दिल्लीका मुसलमान बादशाह गयासुद्धिन तुगलकले राज्य विस्तार गर्ने ऋममा १३६१ सालमा हरिसिंहदेवको राज्य सिमरौनगढमा भीषण आक्रमण गरेपछि, हरि 
सिंहदेव त्यो ठाउँ छाडेर पनौती तथा भक्तपुरमा आई राज्य गर्न थाले तर गयासुद्धिन तुगलकले नेपालको भूसामरिक हैसियत बुक्केपछि, हरिसिंहदेवलाई लखेट्दै काठमाडौं उपत्यका छिर्ने आँट गर्न सकेनन् (शर्मा, २०३३, पृ. १३३)। लिच्छबि राजा राजदेवका पालामा वि. सं. १४०६ मा बड्गालका सुल्तान समसुद्दिनले सिमरौनगढ व्वस्त पारेर त्यसपछि ठूलो सैन्यदस्ता सहित काठमाडौं उपत्यकामा आक्रमण गरी यहाँका मन्दिरहरूमासमेत तोडफोड गर्न र लुटपाट मच्चाउन भ्याए पनि यहाँका स्थानीय जनसाधारणले घर छाडेर जङ्नलमा लुकी छापामार शैलीमा घरेलु हतियार, नोल र लाठीका भरमा मुगल सेनाहरूसँग लडी उनीहरूलाई लखेट्न सफल भएका थिए (अर्याल, २०४३, पृ. ७६)। पृथ्वीनारायणशाहका पालामा वि. सं. १६२० मा नेपालमा आक्रमण गर्न बड्गाल र बिहारका नवाव मिरकासिमले पठाएको गुरगिनखाँको नेतृत्वको फौजलाई गोरखालीहरूले उनीहरूका भएभरका हातहतियारसमेत खोसखास पारेर लखेटेका थिए (भण्डारी, २०२७, पृ. २२)। उनकै पालामा १६१९ सालमा आक्रमण गर्ने किनलोकलाई पनि हातहतियारसमेत खोसखास पारेर सिन्धुलीगढीबाटै लखेटियो (शर्मा, २०३३, पृ. १६१)। १५ ५ सालमा तिब्बतसँग युद्ध शुरु भएपछि, तिब्बतले नेपाललाई जित्न नसकिने अनुभव गरी चीनको सहयोग माग्यो र चीनका दश हजार फौज नेपालमा आक्रमण गर्न नुवाकोट हुँदै पाँचमाने भन्ज्याङसम्म आइपुगेकोमा नेपालीहरूले चतुरतासाथ रातमा जड्नलको चारैतिर आगो लगाइदिएपछि आफू चारैतिरबाट शत्रुको घेरामा परेको ठानी उनीहरू त्यहाँबाटै भागे र अन्ततोगत्वा १६४९ सालमा वेत्रावतीको सन्धि गरियो (भण्डारी, २०२७, प्. ११)। १६७१ सालमा नेपाल अंग्रेज युद्धमा सिन्धुलीगढी किल्लाबाट जनसाधारणले जड़लका अरिंगालका गोला, सिस्नो र अल्लो जस्ता वनस्पतिसमेतको प्रयोग गरेर दुस्मनलाई हायलकायल पारेका थिए। प्रचुर आधुनिक हतियारले सुसज्जित इस्ट इण्डिया सरकारसँगको युद्धमा परम्परागत घरेलु हतियारकै भरमा वैरीहरूलाई हायलकायल पारेको भए पानि अन्ततोगत्वा त्यो युद्धमा
नेपाल पराजित भएता पनि नेपालको भूसामरिक हैसियत र अरुको पराधीनतालाई कुनै हालतमा स्वीकार नगर्ने नेपालीहरूको मानसिकता र अदम्य साहसलाई राम्रोसँग बुक्केको इष्ट इण्डिया सरकारले नेपालमाधि आधिपत्य कायम गर्ने साहस भने बटुल्न सकेन, बरु सुगौली सन्धि गरेर मेची र महाकाली पारिका भ-भागमा नै चित्त बुकाएर फर्कियो (शर्मा, २०३३, पृ. २७३)। १९९१ सालमा तिब्बतसँग फेरि लडाई हुँदा उनीहरूले फेरि हार खाई सन्धि गर्न बाध्य भए (अर्याल, २०४३, पृ. २४१)। यी सबैको कारकतत्व नेपालको अनुकूल भूसामरिक हैसियत अनि त्यसबाट सिर्जित नेपालीको साहस र पराक्रम नै थियो। नेपालको राष्ट्रिय स्वाभिमानको उल्लेखनीय पक्ष नै के हो भने घटनाक्रममा नेपाललाई कसैको नाकाबन्दीले पनि गलाउन सकेन, बरु राष्ट्रिय एकताको भावना चट्टान जस्तै भन् सुदृढ भयो । यहाँको सामाजिक सद्भाव र राष्ट्रिय एकतालाई तहसनहस पार्न तम्सिएकाहरू पनि आफैं लखतरान भई थाकेर लुसुक्क पाखा लागे। यसरी अनादिकालदेखि स्वतन्त्र राष्ट्रका रुपमा विकसित र अक्षुण्ण रही आएकाले अखण्डता, सार्वभौमिकता, सामरिक स्वावलम्बन, देशभक्ति जस्ता सबै गुणहरू नेपालको राष्ट्रियतामा विद्यमान छन् । यो हाम्रो भूसामरिक हैसियतकै कारणले प्राप्त प्राकृतिक वरदान हो ।

\section{नेपालको एकीकरणका प्रयासहरू}

हिमवत्वण्ड भनिएको यो भूभाग इतिहासको कालखण्डमा हमेशा अविभाज्य भने रहेको थिएन र कहिले विशाल राज्यका रुपमा, अनि कहिले विभाजित स-साना राज्यहरूका रुपमा रहने कम चलिरहन्थ्यो (श्रेष्ठ, २०३९, पृ. १००)। यसलाई एकीकरण गर्न समयसमयमा जे जति प्रयासहरू भए, ती सबै प्रयासहरू यसै भ-भागभित्रकै शासकहरूबाट भए, यो भ-भागभन्दा बाहिरबाट होइन। लिच्छबि राजा मानदेव (वि सं पू २१ - पू६२) ले एकीकरण गरी यो राज्यलाई उत्तरमा हिमालयसम्म, पश्चिममा कालीगण्डकी पारिसम्म, पूर्वमा कोशीसम्म विस्तार गरेका थिए (अर्याल, २०३९, 
प्. २९)। कालान्तरमा पुन: विभाजित भएको यो राज्यलाई जुम्ला, सिंजाका खस राजा जितारी मल्लले वि. सं. को १४ औं शताव्दीको चौथो दशकतिर एकीकरण गरी काठमाडौं उपत्यका लगायत पूर्वी नेपालसम्म विस्तार गरेका थिए (भण्डारी, २०२७, पृ. १०७) उनकै पालामा देशभरि नेपाली भाषा विस्तार भएको मानिन्छ। कालान्तरमा पुन: विभाजित भएको यस राज्यलाई राजा यक्ष मल्ल (वि सं. १४६६ - १५३६) ले एकीकरण गरी पूर्वमा मोरझ़सम्म, पश्चिममा पाल्पा तथा गोरखासम्म, उत्तरमा शिकारजोडसम्म र दक्षिणमा गड़ानदीसम्म विस्तार गरेका थिए (अर्याल, २०४३, पृ. ५९ )। तर केही पछि उनैले छोराहरूलाई राज्य भागबण्डा गरेर दिएपछि पुनः विभाजित भएको यस राज्यलाई पाल्पाका राजा मुकुन्दसेन प्रथम (वि. सं. १प७७ १६१०) ले एकीकरण गरी पूर्वमा विजयपुरसम्म विस्तार गरेका थिए (शर्मा, २०३३, प्. २०१)। कालान्तरमा पुन: विभाजित भएको यो राज्यलाई गोरखाका राजा पृथ्वीनारायणशाहले एकीकरण गरी पूर्वमा चौदण्डी, मोरड़ किराँत प्रदेशसम्म, पश्चिममा गण्डकी प्रदेशसम्म राज्य विस्तार गरी नेपालको राजधानी काठमाडौं कायम गरे । पृथ्वीनारायणशाहलाई पनि उनका भाइ दलमर्दन शाहले राज्य भागबण्डा गर्न प्रस्ताव नराखेका होइनन, तर उनले सो प्रस्ताव ठाडै इन्कार गरे। राजा रणबहादुर शाह नावालक भएका बेला आफ्नो नायवी शासनकालमा रानी राजेन्द्रलक्ष्मी, राजकुमार बहादुर शाह र मुख्तियार भीमसेन थापासमेतको सक्रियतामा राज्य थप विस्तार भई पश्चिममा बाइसी चौबिसी राज्य लगायत आलमोडा, कुमाउँ, गढवालसम्म र पूर्वतर्फ सिक्किमसम्म राज्य विस्तार भयो। वि. सं १६७१ सालमा घटित नेपाल अंग्रेज युद्धमा नेपालले व्यहोरेको पराजयको फलस्वरुप सुगौली सन्धि भई नेपालले मेचीपारि र महाकालीपारिका भ-भाग गुमाउनुपरेकाले राज्यको क्षेत्रफल संकुचित भयो। प्रधानमन्त्री जड्ग बहादुर राणाका पालामा उनकै सक्रियतामा जम्मा क्षेत्रफल ९२०७ बर्गकिलोमिटर भएको बाँक, बर्दिया, कैलाली र कळ्चनपुर ब्रिटिस सरकारबाट पुन: नेपाललाई
प्राप्त भएपछि नेपालको भ-भाग केही विस्तार भई वर्तमान हैसियत प्राप्त भयो (श्रेष्ठ, २०पै, पृ. ६१ ) ।

\section{भूसामरिक हैसियतबाट राष्ट्रियता निर्माण}

नेपालमा १२प वटा जातजाति रहेका छन् जसमा परापूर्वकालमा इरानतिरबाट आएका आर्य, ककेसियाबाट आएका खस, मंगोलियाबाट आएका मंगोल अनि दक्षिण भारततिरबाट आएका आर्यब्राहमणहरूको सम्मिश्रण छ। राष्ट्रिनिर्माता पृथ्वीनारायण शाहले नेपाललाई चार वर्ण छत्तीस जातको फलबारी भनेका छन्। यहाँका हिमाल, पहाड र तराईमा बस्ने सबै जातजातिहरूमा म नेपाली हुँ भन्ने आत्मबोधका साथै एउटै राष्ट्रिय साइनोमा आवद्ध आत्मीय भावना छ, अनि एक अर्काको संस्कृति, भेषभूषा, रीतिरिवाजप्रति सम्मान र सहिष्णुता देखाउने प्रवृत्ति विद्यमान छ। चाहे आदिवासी होस्, चाहे अनादिवासी होस, चाहे आप्रवासी होस, ती सबैको सम्मिश्रण, भाइचारा र एकताबाटै राष्ट्रिय एकता सुदृढ भएको छ। मंगोल समुदायमध्येका पूर्वी नेपालमा बस्ने मुन्धुममार्गी प्रकृतिपुजक किरातहरूको संस्कृतिबाट वैदिक सनातन धर्मावलम्वी क्षेत्रीबाहुनहरू पनि प्रभावित छन् र मन्दिरमा वलि दिने प्रचलन, धामी भांक्रीको प्रचलन जस्ता अभ्यासहरू अवलम्बन गरेका छन्। पश्चिमी नेपालका भोटे जातिहरूबाट प्रभावित भई त्यहाँका क्षेत्रीबाहुनहरू मष्टपूजक रहेका छन् (खंड्का, २०७२, पृ. ९६)। वैदिक सनातन धर्मीहरू पनि मंगोल समुदाय जस्तै मांशाहारी भएका छन् । वौद्ध धर्मावलम्बीबाट प्रभावित हिन्दूहरूले बुद्धलाई भगवान् विष्णुकै नवौं अवतार मानेका छ. र यो कुरा नेपालमा नै रचित अठार पुराणहरूबाट स्थापित भएको छ। सनातन धर्मावलम्बीहरूका कतिपय मन्दिरहरूमा गैरब्राह्मण वा गैरक्षेत्री समुदायका अर्थात् मंगोल समुदायका पूजारी रहने गरेका छन्। तामाङ समुदायको जन्म तथा मृत्यु संस्कार लगायतका कतिपय कर्मकाण्डका ग्रन्थहरू तिब्बती लिपिमा भए पनि तिनको भाषा संस्कृत छ, र तिनमा वैदिक सनातन धर्म अन्तर्गतकै देवीदेवताहरूको पुकारा गरिएका श्लोकहरू छन्। नेपालमा हिन्दू, 
वौद्ध, इस्लाम, किरात, क्रिश्चियन, प्रकृति लगायत १० वटा धर्म मानिन्छन् र ती सबै धर्महरूबिच सदासर्वदा धार्मिक सहिष्णुता रहिआएको छ र धर्मको नाममा कहिल्यै पनि राग, द्वेष, घृणा वा वैमनस्यताको स्थिति सिर्जना भएन। बुद्धधर्म नेपालकै योगदान हो । हिन्दूले वौद्धगुम्वाको र बौद्धले हिन्दू मन्दिरको दर्शन गर्ने परम्परा यहाँ छ। यसबाहेक किरात, हिन्दू र वौद्ध धर्मावलम्बीहरूमा पनि एकअर्काको संस्कृति, परम्परा र पूजा अनुष्ठानको अवलम्बन गर्ने प्रवृत्ति विद्यमान छ, । आजका नयाँ पुस्ताहरूले त हिन्दू, वौद्ध, इस्लाम, किरात, क्रिश्चियन सबैका मुख्य मुख्य चाडपर्बहरू दशैं, तिहार, ल्होसार, इद, क्रिसमस, उँधौलीउँभौली, बुद्धजयन्ति, साकेला, माघी, गौरा, छठ, होली, तीज आदिमा सहभागी हुने र संयुक्तरुपमा रमाउने गईईन् (शर्मा, २०७६, पृ. १७४)। यसप्रकार आफ्नो विशिष्ट भूसामरिक हैसियत भएका कारणले गर्दा यस भ-भागभित्र बसोबास गर्ने बुद्धमार्गीहरू, मुन्धुम मार्गी किरातहरू र वैदिक सनातनधर्मीहरू समष्टिगत रुपमा एकआपसमा सद्भावनापूर्वक घुलमिल भई पृथक प्रकारको मौलिक संस्कृतिको संरचना भएर नेपाली राष्ट्रियताको आधारशीलाको निर्माण हुन गएको छ। तसर्थ यो राष्ट्रियता जातीय वा साम्प्रदायिक राष्ट्रियता नभएर भौगोलिक राष्ट्रियता हो, जसको कारकतत्व यहाँको भूसामरिक हैसियत नै हो ।

चीनसंग नेपालको सांस्कृतिक आदान प्रदान र व्यापारिक सम्बन्ध धेरै प्राचीन छ। ईसापूर्व पहिलो शताव्दीमा चीनका हान राजवंशका पालामा विशेषत रेशम तथा रेशमी लत्ताकपडा निर्यात गर्ने प्रयोजनार्थ चीनले खोलेको मार्गलाई रेशम मार्ग भनिन्छ। यो मार्ग अफगानिस्तान, उज्वेकिस्तान, पाकिस्तान, इरान, मिश्रसम्म पुगेको थियो र सबै प्रकारको व्यापार यसै मार्गबाट हुन्थ्यो। यसै मार्गको एउटा प्रशाखाले नेपाललाई काठमाडौंबाट तिब्बत हुंदै चीनसँग जोडेको थियो (सँग्रौला, २०७६, पृ. पू६७) जसको फलस्वरुप नेपाल पनि रेशम मार्गको पहुंचभित्रका सबै देशहरूसँग जोडिन सकेको थियो। यही मार्गले काठमाडौंलाई नेपालको केन्द्र बनाइदियो
अनि तिब्बत र चीनसँग सुमधुर सम्बन्ध पनि स्थापित गरिदियो। यसबाट एकातिर चीनले दक्षिण एसिया प्रवेश गर्ने ट्रान्जिट मार्गको हैसियत नेपाललाई प्राप्त भयो र अर्कातिर नेपालको व्यापार र सांस्कृतिक आदानप्रदान पनि उत्तर र दक्षिण दुबैतिर विस्तार भयो । रेशम मार्गको एक बिन्दु भएकै कारणले गर्दा नेपालले दक्षिणतिर मगध राज्यमा ऊन र कागज निर्यात गर्थ्यो भने तिब्बतमा चाँदी र सुनका सिक्का निर्यात गर्थ्यो। यति हुँदाहुँदै पनि भौगोलिकरुपमा उत्तरतिर दुर्गम पथ र दक्षिणतिर सुगम पथ भएको कारणले चीनसँगभन्दा भारतसँग बढ़ी सान्निध्य हुनु स्वाभाविकै थियो र अहिले पनि त्यस्तै भइरहेको छ। सान्निध्यता बढ़ी भएपछि उतारचढाव र खटपट वा समस्या पनि बढी नै हुनु स्वाभाविकै हो। फलस्वरुप चीन र नेपालबीचको द्वैध सम्बन्धमा अहिलेसम्म कुन खटपट देखिएको छैन तर भारतसँग भने बेलाबेलामा यस्तो भैरहने गरेको छ (शर्मा, २०४३, पृ. १६)। यो पनि नेपालको भूसामरिक हैसियतले नै उब्जाएको स्थिति हो।

\section{सम्भावित अवगालप्रति सतर्क हुन सिकाउने भूसामरिक हैसियत}

नेपाल दुई विशाल देशहरूका बिचमा रहेको कारणले गर्दा यसले जुनसुकै शक्ति राष्ट्रहरूको प्रतिस्पर्धामा कसैतिर पनि नलागी आफ्नो राष्ट्रिय हित र सुरक्षालाई मात्र ध्यान दिनुपर्ने हुन्छ। चीन बिरोधी वा भारत बिरोधी तत्वहरूले नेपालको भूसामरिक हैसियतको दुरुपयोग गर्दे यहाँ बसेर तीमध्ये कुनै पनि देशका विरुद्धमा खिलाफमा कुनै प्रकारको गतिविधि गरेमा त्यसको अवगाल नेपाललाई आइलाग्छ। यस कुरामा सतर्क हुन हाम्रो भूसामरिक हैसियतले सिकाउँछ। तिब्बतबाट दलाइलामा निर्वासित भएपछि उनका पक्षधरहरूले भौगोलिक निकटताका कारणले नेपाली भूमिबाट चीनसंग कथित राजनैतिक अधिकार माग गर्ने नाममा चीनबिरोधी गतिविधि गर्ने प्रवल सम्भावना थियो र केही हदसम्म त्यस्तै भयो पनि। नेपालले पहिलेदेखि नै अँगालेको एक चीन नीति अनुसार तिब्बतलाई चीनकै 
एक अभिन्न अंग मानेको छ। सन् १९६० को दशकदेखि दलाइ लामाका पक्षधर खम्पाहरूले विदेशी तत्वको मद्धत लिएर नेपालको मुस्ताङको दुर्गम भेकमा बसी चीनसाग कथित राजनैतिक अधिकार माग गर्ने वहानामा चीन बिरुद्ध आतड्ककारी गतिविधि गर्नथाले। कुनै पनि देशको नागरिकले अर्काको देशमा गएर अधिकार माग गर्ने हैसियत राख्दैन, मिल्दैन त्यसैले आफ्नै देशमा बसेर माग गर्नुपछ भन्ने मान्यता विपरीत खम्पाहरूले नेपालमा बसेर चीन बिरुद्ध ज्यादती नै गरेका थिए। त्यसैले यिनीहरूको कुकृत्य धेरै बढ़न थालेपछि, नेपालले २०३१ सालमा सैनिक कारवाही गरेर उनीहरूलाई निस्तेज पारिदिएपछि, सुरक्षाका सवालमा चीनको विश्वास जित्न सफल भएको थियो (खरेल, २०७६, पृ. १६६)। अब तिब्बती भ-भागको सुरक्षाको सवालमा नेपालको भ-भागबाट कुनै खतरा छैन भन्ने कुरामा चीन विश्वस्त रहेको छ।

नेपालको भूसामरिक हैसियतकै कारणले गर्दा भारतले धेरै पहिलेदेखि नै नेपाललाई आफ़नो सुरक्षा कवच ठान्दछ। सन् १९५० मा तत्कालीन भारतीय प्रधानमन्त्री जवाहरलाल नेहरूले भारतीय संसदमा दिएको अभिव्यक्तिमा भनेका थिए -हिमालयले चीरकालदेखि मजबूत सिमानाको भूमिका खेलिरहेको छ। त्यसैले नेपालमा केही नराम्रो भए वा उक्त सिमाना तोडिएमा वा त्यसलाई कमजोर पारिएमा त्यसले भारतका लागि सुरक्षा खतरा निम्त्याउने छ (खरेल, २०७६, पृ. १६७)। उनको अभिव्यक्तिबाट उनले नेपालको भूसामरिक हैसियत राम्ररी बुभकका थिए भन्ने देखिन्छ। सन् १९६२ मा भारतले चीनसँग युद्धमा होमिनुपरेपछि नेहरूको भनाइको अभै पुष्टि भएको भारतलाई अनुभव भयो जसको फलस्वरुप नेपाललाई आफनो सुरक्षा छाताभित्र राखेर हेरे उसको दृष्टिकोण कनै विस्तार भयो। नेपालले २०१६ सालतिर छिमेकी मित्रताको नाताले सद्भावनास्वरुप केही समयका लागि प्रयोग गर्न भद्र समभदारीबाट अनुमति दिएको नेपालको भ-भाग कालापानी, लिपुलेक र लिम्पियाधुरालाई भूसामरिक महत्व भएकै कारणले भारतले यति लामो समयसम्म
पनि नेपाललाई फिर्ता गर्न धिडन्याइं गरिरहययो र यहाँको कमजोर राजनीतिक इच्छाशक्तिको फाइदा उठाइरहयो । २०७७ सालमा नेपाल सरकारले सो विषयमा गरेको पहलकदमी र मुलुकका सम्पूर्ण राजनीतिक शक्तिहरूले सर्वसम्मत रुपमा होस्टेमा हैंसे गरेर एकजुट भएपछि, ती ठाउँहरू फिर्ता आउने अनुकूल परिस्थिति सिर्जना भएको छ।

नेपालको भूसामरिक हैसियतकै कारणले गर्दा विभिन्न शक्तिसमूहहरू र विदेशी अवाज्छित तत्वहरूले यहाँको भूमि प्रयोग गर्दे आफ्नो कुत्सित अभीष्ट पूरा गर्न लालायित हुने गर्दछन्। पहिलो कुरा त नेपाल ज्यादै सुन्दर देश भएकाले सबैको आकर्षणको केन्द्र हुनु स्वाभाविकै हो। त्यसको अलावा चीन विरोधी तत्वहरू र भारत बिरोधी तत्वहरू दुबैथरीले नेपालको भूमि प्रयोग गरेर आफ़नो गतिविधि गर्न चाहन्छन्। भारत बिरोधी तत्वहरूले भारतको राजनैतिक प्रणाली र त्यहाँको सांस्कृतिक मूल्य र मान्यतामा आघात पार्न चाहन्छन् भने चीन बिरोधी तत्वहरूले चीनको राजनीतिक र आर्थिक उदयमा बाधाव्यवधान गर्न चाहन्छन् अनि यस्ता गतिविधि नेपालमा बसेर गर्नका लागि यहाँको भूसामरिक अवस्थाबाट लोभिन्छन् । यो अभीस्ट पूरा गर्न उनीहरूले सर्वप्रथम त नेपाललाई नै कमजोर वा बिफल राष्ट्र बनाउने रणनीतिको उपयोग गर्दछन् ता कि उनीहरूलाई कुनै न कुनै बहाना बनाएर यहाँ बसी चलखेल गर्न सजिलो होस्। यसका लागि उनीहरूले नेपालमा राजनैतिक अस्थीरता सिर्जना गर्ने, राज्यको कमजोर इच्छाशक्तिको अवस्था सिर्जना गर्ने अनि यहाँको सामाजिक सहिष्णुता र सामाजिक सद्भावना खत्तम पारेर समाजलाई विथोल्ने कार्यमा प्रत्यक्ष वा परोक्ष मूर्त तथा अमूर्त भूमिका खेल्ने जस्ता कुकृत्य गर्ने सम्भावना रहन्छ। त्यसैले नेपालले आफूलाई अवगालबाट जोगाउँदै आफ़नो भूमि अरु बिरुद्ध प्रयोग हुन नपाउने अवस्था सिर्जना गर्नुपर्दछ। हामीले के कुरा भुल्नु हुँदैन भने नेपालको आन्तरिक मामिलामा चलखेल गर्नका लागि विभिन्न शक्तिसमूह तथा विदेशी अवनज्छित तत्वहरू नेपालको भूमि प्रयोग 
गर्न लालायित हुने प्रमुख कारण यहाँको भूसामरिक हैसियत पानि हो।

\section{इतिहासबाट सिक्नुपर्ने पाठ}

पृथ्वीनारायण शाहले भनेका थिए - चीन बादशाहसित ठूलो घाहा राख्नु। दखिनको समुन्द्रका बादशाहसित घाहा ता राख्नु तर त्यो महाचतुर छ (गौतम, २०४४ पृ. १७)। उनको दीव्योपदेशमा छिमेकीसँग सुमधुर सम्बन्ध राख्नुपईई भन्ने सन्देश पाइन्छ अनि छिमेकीसँग सम्बन्धमा तीक्तता भयोभने दुर्भागय निम्तिन्छ भन्ने मत पनि अन्तर्निहित छ। पृथ्वीनारायणशाहका सेखपछि एकीकरणका क्रममा पूर्वमा टिस्टा नदीसम्म नेपालको सिमाना विस्तार हुंदा सिक्किम राज्यको केही भाग पनि नेपालले लिएको थियो र सिक्किमको मनमा यसबाट उत्पन्न तीक्तता कायमै थियो। यो कुरा बुक्केका अंग्रेजहरूले १९७१ सालमा नेपालसँग युद्ध घोषणा गर्दा सिक्किमका राजालाई पनि नेपालको विपक्षमा खडा गर्न समर्थ भए। अंग्रेजले नेपाललाई युद्धमा जितेपछि सिक्किमको पहिले नेपालले लिएको भ-भाग सिक्किमलाई नै दिइनेछ भन्ने आश्वासन दिई सिक्किमको भविष्यको स्वतन्त्रताको सुरक्षा गर्ने वचनसमेत दिएपछि सिक्किमले स्वीकार गरी नेपालको विपक्षमा खडा भयो। त्यस्तै गरी नेपालले सन् १७६६ मा छिमेकी तिब्बतसँग अनावश्यक बखेडा भिकेर युद्ध गरी पहिलेको सुमधुर सम्बन्धलाई बिथोल्यो (सँग्रौला, २०७६, पृ. २५३)। युद्धमा नेपालको जित भएर सन् १७९२ मा सन्धि भए पनि आपसी सम्बन्धमा आएको तीक्तता मेटिन सकेन। यसको फलस्वरुप अंग्रेजहरूले नेपालमा आक्रमण गरेपछि नेपालले छिमेकीको हैसियतले चीनसँग सहयोगको याचना गर्दा चीनले साफसँग इन्कार गरिदियो। आधुनिक हतियारले सुसज्जित अंग्रेजहरूसँग घरेलु हतियारको भरमा एक्लै युद्ध गर्नुपर्दा नेपालको पराजय स्वाभाविकै थियो जसको फलस्वरुप मेची र महाकालीपारिका भ-भाग गुमे। नेपालले त क्षति व्यहोरिहाल्यो तर नेपाललाई सहयोग नगरेको परिणाम चीनका लागि पनि महंगो
सावित भयो। नेपाललाई पराजित गरेपछि, अंग्रेजहरूले तिब्बतलाई पनि निशाना बनाए र तिब्बतको निकै ठूलो भ-भाग नियन्त्रणमा लिई बाँकी रहेको तिब्बतलाई पनि ब्रिटिस उपनिवेश कायम गरे (सँग्रौला, २०७६, प्. ६०५-६०९)। पृथ्वीनारायण शाहले दक्षिणको बादशाह भनेर त्यतिबेला ब्रिटिस उपनिवेशबादीहरूलाई लक्षित गरेका थिए। आज दक्षिणमा ब्रिटिस उपनिवेश छैन तर पनि त्यहाँ उपनिवेशबादी सोचको धडधडी बाँकी नै छ, र उनको दिव्योपदेश आज पनि सान्दर्भिक नै छ।

\section{भूसामरिक हैसियतबाट परराष्ट्र नीति निर्माण}

पृथ्वीनारायण शाहले नेपाललाई दुई ढुड़ाका बिचको तरुल भनेका थिए। वास्तवमै यो देश अनादिकालदेखि नै दुई ढुड़गाका बिचको तरुल नै रही आएको छ। तरुल अब तरुल मात्र नरहेर नेपालका लागि राष्ट्रिय सुरक्षा र सर्वांगीण विकासमा लागि अवलम्बन गर्नुपर्ने रणनैतिक सिद्धान्त नै बन्न पुगेको छ। तरुल भएक कारणले एकातिर यसले दुईतिरका ढुझ़ाहरूलाई जुध्न नदिने रक्षा कवचको काम पनि गरेको छ भने अर्कातिर ढुड़गाहरूले आफलाई दखल नदिउन भनेर सजग पनि बनेको छ। भारतले सन् १९७४ मा सिक्किम कव्जा गरेपछि, नेपाल अभौ सतर्क बनेको छ भने अर्कातिर भारत सन् १९६३ मा चीनसंग युद्धमा होमिएपछि त्यसको परिणामस्वरुप चीनसंगको उसको चीसोपन र शंकालु मनोवृत्ति अद्यापि कायमै रहेकाले पनि नेपाललाई चिढ्यायो भने नेपालमा चीनियां प्रभाव बढ्छ, भन्ने उसमा मनोवैज्ञानिक त्रासले घर गरेको छ। त्यसैले भारत नेपाललाई भरसक फकाएर नभए तर्साएर भए पनि यहाँ आफ्नै प्रभाव कायम राख्न चाहेको जस्तो देखिन्छ। भारतले कमश: २०२७ साल, २०४६ साल र २०७२ सालमा गरेका तिन वटा नाकाबन्दीहरू यसै कुराका द्योतक थिए, यद्यपि स्वाभिमानी नेपालीहरूका सामु ती नाकाबन्दी कामयावी भएनन् बरु भारतकै बेइज्जत भयो। अब भारत अरु नै तरिकाले आफ्नो गुमेको इज्जत फर्काउन लालायित छ। नेपालले आफ्नो नक्सामा कालापानी, लिम्पियाधुरा र लिपुलेक समवेश गरेर हालै गरेको 
परिवर्तनबाट भारतले असहज अनुभव गरेको भए पनि छिमेकी भएको नाताले गर्दा अन्ततोगत्वा भारतले अन्य धैरै व्यवहारजन्य घनिष्ठता, विश्वव्यापीकरणले ल्याएको रुपान्तरण, आन्तरिक विषयवस्तु र अन्य राष्टहरुसँगको सम्बन्धले खेलेको अहम् भूमिकाले गर्दा नेपालको तथ्यमा आधारित दाबीलाई मान्यता दिन करैलाग्नेछ, (लामा, २०७७६।९, कान्तिपुर दैनिक)। जेसुकै भए पनि चीन र भारत दुबै नेपालका छिमेकी मित्र राष्ट्र हुन् र ती दुबै देशहरुसँग सुमधुर सम्बन्ध अपरिहार्य छ। दुबै देशहरू स्थीर राजनैतिक प्रणाली सहित विशाल र व्यापक बजार भएका देश हुनाले ती दुईका बीचमा अवस्थित नेपाल उनीहरूका लागि महत्वपूर्ण स्थल हो। त्यसैले ती दुबैसँग सहकार्य गर्नैपर्ने आवश्यकता रहेको छ र चतुर कुटनीति र सुरक्षा नीति अवलम्बन गर्दे दुबै छिमेकीहरूलाई सँगसँगै हातेमालो गरेर हिंडाउनुपर्ने र आफू पनि उनीहरूसँग हातेमालो गरेर हिंड्नुपर्ने अवस्था छ।

\section{भूसामरिक हैसियतलाई थप मजबूत बनाउनका लागि अवसर}

अबको युग भसामरिक हैसियतलाई विगतमा कैं युद्धकौशलका लागि उपयोग गर्ने युग होइन। संयुक्त राष्ट्र संघको स्थापना र सक्रियताको फलस्वरुप विश्वमा युद्धको औचित्य लगभग समाप्त भैसकेको छ। त्यसैले भूसामरिक हैसियतलाई अब आर्थिक विकास र समृद्धिको लागि उपयोग गर्नुपर्ने समयको माग रहेको छ। आफ भूपरिवेष्टित देश भएको, छिमेकी मुलुकहरू दुईवटा मात्र भएका, पूर्व-पश्चिम र दक्षिण तिनतिखाट भारतले घेरिएको अनि विकट र अगम पहाडका कारणले उत्तरमा चीनसंगको सम्पर्क र आदानप्रदान सहज नभएको स्थितिमा नेपालले दुबै छिमेकी लगायत सबै मित्रराष्ट्रहरूसँग अन्तर्राष्ट्रिय कानुन एवं संयुक्त राष्ट्र संघको बडापत्रको पालना गर्दै शान्तिपूर्ण आग्रहबाट समदूरी (Equidistance), समसामिप्यता (Equiproximity), गतिशील तटस्थता (Dynamic neutrality), एक चीन नीति, पञ्चशीलको सिद्धान्त, सन्तुलित छिमेकी नीति (Balanced neighbourhood policy) अवलम्बन गरी आएकाले यसैलाई निरन्तरता दिनुपर्ने आवश्यकता छ (थापा, २०७६, पृ. २३६)। तसर्थ नेपालको भूसामरिक हैसियतलाई थप मजबुत बनाउने अवसरका रुपमा निम्नलिखित विषयहरूलाई कारकतत्वको रुपमा लिन सकिन्छ:-

\section{(क) पर्वपश्चिम राजमार्ग र अरनिको राजमार्ग}

छिमेकी भारतले त्यतिबेला राम्रो नमान्दा नमान्दै पनि राजा महेन्द्रले २०१६ सालमा पूर्वपश्चिम राजमार्ग र सन् १९६६ मा नेपाललाई चीनसंग जोड्ने अरनिको राजमार्गको निर्माण गरेपछि, भारतसँग मात्र बढ़ी मात्रामा निर्भर हुनुपर्ने स्थितिमा कमी आउन थालेको हो। साथै अहिले आएर एशियाली राजमार्गको नेपालमा पर्ने रुट नै पूर्वपश्चिम राजमार्ग भएपछि, दुई छिमेकीसँग समदूरीको स्थितिमा पुग्ने आधारशिला तयार भएको छ।

\section{(ख) यातायात विस्तार}

पछिल्ला दिनहरूमा भारतसँग रेलवे सम्बन्ध, चीनसँग रसुवा नाकाबाट राजमार्ग तथा रेलवे सम्बन्धको प्रकियाको सुरुवात, कोशी राजमार्गलाई किमाथांका हुंदै तिब्बतसँग जोड्ने कार्यले तीव्रता पाएको अवस्था आदिबाट दुबै छिमेकीहरूसँग अभै नजिकिने अवस्थाको सिर्जना भई परनिर्भरताको स्थिति ऋमश: घट्दै जाने ऋममा छ। यसबाहेक काठमाडौंको अतिरिक्त निजगढ, लुम्बिनी, पोखरा, विराटनगर लगायतका ठाउँहरूमा पनि अन्तर्राष्ट्रिय विमानस्थलहरूको निर्माण गर्न प्रक्रिया अगाडि बढेको हुँदा अन्य मुलुकहरूसँगको सम्बन्ध, सम्पर्क र सहकार्यले थप तीव्रता पाउने भएको छ, जुन नेपालको विकास र समृद्धिका लागि महत्वपूर्ण छ।

\section{(ग) ब्रिक्स राज्यहरूको उदय}

अर्थ व्यवस्था तीव्र दरमा वृद्धि भइरहेका विकासोन्मुख वा नवऔद्योगिक देशहरू ब्राजिल, रुस, भारत, चीन र दक्षिण अफ्रिका (यीमध्ये रुस चाहिं विकसित राज्यमा 
पर्दछ) समकालीन विश्वमा राज्यको एक वा द्विध्रुवीय समीकरणलाई नष्ट गर्दै ब्रिक्स राज्यका रुपमा सँगठित भएपछि अन्तर्राष्ट्रिय राजनीतिमा बहुपक्षीयताको उदय हुनाको साथै राज्यहरूबिचको सम्बन्धलाई आर्थिक सहकार्यमा उन्मुख गराउनुपईछ भन्ने अवधारणाले विश्वव्यापी मान्यता पाएकाले राज्यहरूका बिचको आपसी सहभागिता नेपालको लागि पनि विशेष उपयोगी हुने देखिएको छ। हाम्रा घनिष्ठ छिमेकी अनि एशियाका दुई ठूला शक्तिहरू भारत र चीन पनि आपसी टकरावलाई न्यून गर्दे अर्थतन्त्रको विकासमा सहकार्य गर्ने अभिलाषासाथ नजिकिने क्रममा छन् जसको फलस्वरुप ती दुईबीच सैन्यबलको प्रयोगको सम्भावना न्यून हुँदै गइरहेकोबाट शान्तिप्रिय नेपालका लागि सुखद सन्देश प्रवाह भएको छ।

\section{(घ) असंलग्नता र पन्चशील}

नेपालले सीमावर्ती छिमेकीहरू लगायत सबै देशसँग असंलग्नता र पन्चशीलको सिद्धान्तको परिपालनासहित शान्तिपर्ण एवं समान व्यवहार गर्ने रणनीति अवलम्वन गर्दे मित्रतापूर्ण सम्बन्ध कायम राखेपछि, आफ़नो स्वाधीनतामा कतैबाट पनि चुनौतीको सिर्जना हुने सम्भावना रहंदैन भन्ने मान्यतालाई आफ्नो कुटनीतिको आदर्श सिद्धान्त बनाएकाले दुई छिमेकीसँग समदूरीको सम्बन्ध कायम राख्ने आधारशिला तयार भएको छ जुन हाम्रो भूसामरिक हैसियतका लागि सार्थक र लाभदायक छ।

\section{(ङ) जलविद्युत संम्भाव्यता}

नेपालमा अविरल बगीरहने बेगवान् नदीहरू प्रचूर मात्रामा छन् र तिनले नेपाललाई जलस्रोतको धनी देश बनाएकाछन् यद्यपि जलस्रोतको पर्याप्त प्रयोग र परिचालन हुन सकेको छैन। नेपालको जलविद्युत संम्भाव्यता ๘३००० मेगावाट रहेको छ। त्यसको आधा मात्रै उत्पादन गर्न सकेमा पनि मुलुकको अर्थतन्त्रमा कायापलट हुनसक्छ। भारत, बड्गलादेश, चीन हाम्रो विद्युत बिक्री हुने नजिकका ठूला बजार हुन्। तसर्थ
हाम्रो जलस्रोतलाई समुचित परिचालन गरी जलविद्युत उत्पादनमा जोड दिनु जरुरी छ।

\section{(च) पर्यटन}

नेपाल अत्यन्तै सुन्दर देश हो। मनोहर प्राकृतिक दृश्यले गर्दा यो विदेशी पर्यटकहरूको आकर्षणको केन्द्र बन्नपुगेको छ। यसबाहेक विश्वका सबैभन्दा अग्ला १४ वटा हिमालमध्ये $₹$ वटा नेपालमा नै छन् । त्यसैले विदेशी पर्वतारोहीहरूका लागि यो राम्रो गन्तव्यस्थल हो। दृश्यावलोकन पर्यटन र पर्वतारोहण पर्यटनका अतिरिक्त बुद्धको जन्मस्थल लुम्बिनी र सीताको जन्मस्थल जनकपुर यहीं भएकाले धार्मिक पर्यटनका लागि पनि प्रचूर सम्भावना बोकेको देश हो नेपाल। विश्वभरका मुस्लिमहरूका लागि मक्का, मदिना अनि विश्वभरका क्रिश्चियनहरूका लागि जेरुसेलमको जुन महत्व छ, विश्वभरका बौद्धमार्गीहरूका लागि लुम्बिनी र विश्वभरका हिन्दूहरूका लागि जनकपुरको त्यत्तिकै महत्व छ। तसर्थ यी ठाउँहरूको समुचित विकास गरी विश्वसामु व्यापकरुपमा चिनाउन सके धार्मिक पर्यटन तीव्रतासाथ फस्टाउन सक्ने अवस्था छ।

\section{(छ) जलवायु परिवर्तनको प्रयोगस्थल}

आजको विश्व जलवायु परिवर्तनको प्रतिकूल प्रभावबाट आक्रान्त छ। खस्कँदो प्राकृतिक प्रणाली, वनविनास, मरुभूमीकरण, वायुमण्डलमा पातलिंदो ओजोन तह, हरितगृह असर, बगदो कृषियोग्य भूसतह वा माटो, तापमान उच्च हुंदै गइरहेको अवस्था, जैविक विविधतामा तीव्र गतिमा हुन गइरहेको ह्रास, वायु प्रदूषण, जल प्रदूषण, प्राकृतिक सम्पदामाथिको अनुचित शोषण र दोहन आदि समस्याहरू सर्वत्र छन् । हाम्रो देशमा हिमालय सम्पदा प्रचूर मात्रामा भएकाले यहाँका हिमालयहरू पनि यसबाट प्रभावित छन् । अर्कातिर समुद्र सतहबाट पूर मिटरदेखि द६ ६ द. मिटरसम्मको उचाइ भएको भूधरातलीय विविधतायुक्त देश भएकाले यो ठाउँ जलवायु परिवर्तनको उपयुक्त प्रयोगस्थल हुन सक्दछ (Baniya, 2076, p. 43)। 


\section{निष्कर्ष}

इतिहासको अवलोकन गर्ने हो भने विगतमा जुनसुकै देशले पनि युद्धबाटै आफ़नो देशको रक्षा गरेको पाइन्छ र नेपालमा पनि भएको त्यही नै हो। हाम्रा पूर्खाहरूले नेपालको भूसामरिक हैसियतको सम्यक उपयोग गरेर बहादुरी देखाई स्वदेशको रक्षा गरेको इतिहासप्रति हामीले गर्व गर्नुपछ। तर वर्तमान परिप्रेक्षमा संलग्न देशहरूका लागिसमेत युद्धको औचित्य लगभग समाप्त भइसकेको वर्तमान विश्वमा नेपाल जस्तो असंलग्न तथा शान्तिप्रीय देशका लागि युद्ध भनेको कल्पनाभन्दा बाहिरको वस्तु हुनजान्छ। त्यसैले नेपालले आफ्नो भूसामरिक हैसियतलाई अब विकास, समृद्धि तथा अन्तर ाष्ट्रिय भाइचाराका लागि मात्र प्रयोग गर्नुपर्ने समयको माग रहेको छ। दुई ठूला देशहरूका बिचमा अवस्थित देश भएको कारणले गर्दा नेपालले आफ़नो अस्तित्व र स्वाधीनताप्रति सधैं सतर्क र जागरुक भइरहनुपछ। भारत हाम्रो असल र घनिष्ठ छिमेकी हो तथापि विगतको तिन पटकको नाकाबन्दीबाट पाठ सिक्न पनि बिर्सनु हुन्न। के कुरा हृदयड्गम गर्नुपछ भने स्वाधीनताउपरको चुनौती छिमेकीको आधिपत्य शक्तिबाट मात्र आउने होइन, बरु आफ़न बिफल कूटनीति र कमजोर राष्ट्रिय परिवेशबाट पनि आउने हो। तसर्थ आफनो भूसामरिक हैसियतको उपयोग गरेर विकास र समद्धिका क्षेत्रमा लाभान्वित हुन नेपालले अंगाल्नुपर्ने निम्नलिखित विषयहरू सुभावको रुपमा प्रस्तुत गरिएको छ :-

\section{सुभावहरू}

(क) छिमेकी मित्रराष्ट्रहरूको भूसामरिक अभिरुचिलाई कुटनैतिक र सन्तुलित सम्बोधन

चीन र भारत दुबै निकटवर्ती छिमेकी देश भएकाले नेपालप्रति उनीहरूको भसामरिक अभिरुचि रहनु स्वाभाविकै हो। यहाँको भौगोलिक संरचनाले गर्दा पनि छिमेकी मुलुकहरूको सुरक्षा व्यवस्थामा यो संम्वेदनशील बन्न पुगेको छ। चीन र भारत हाम्रा घनिस्ट छि,मेकी मित्रराष्ट्र हुन् भने बाँकी सबै देशहरू पनि हाम्रा घनिष्ट
मित्रराष्ट्र हुन् त्यसैले नेपालले आफ्नो भूसामरिक हैसियतलाई कसैको विरुद्धमा पनि प्रयोग गर्देन र प्रयोग हुन पनि दिंदैन। चाहे चीनलाई विरोधी राष्ट्र घोषणा गरेर चीनको उदयलाई जसरी पनि रोक्ने भनी अमेरिकी राष्ट्रपति ट्रम्पले जारी गरेको सुरक्षा रणनीति २०१७ होस, चाहे सीआईएको तिब्बत स्वतन्त्रता मिसन होस, चाहे पश्चिमी शक्तिगुटले चीनको उदयमा व्यवधान गर्ने उद्देश्यले अँगालेको चीन कन्टेनमेन्ट रणनीति होस, चाहे पश्चिमी शक्तिगुटले भारतको रुस र इरानसंगको सम्बन्धमाथि कडा निगरानी राख्न अँगालेको भारत कन्टेनमेन्ट रणनीति होस, नेपालले ती विषयहरूसँग सरोकार राख्नुहुंदैन, अनि ती विषयहरूलाई पृष्ठपोषण हुनेखालका गतिविधि नेपालको भूमिमा हुन पनि दिनुहुंदैन ।

\section{(ख) छिमेकी मित्रराष्ट्र भारतसँग घनिष्टता}

भारतसंग पूर्व, पश्चिम र दक्षिणमा खुला सिमानाका कारण रोटीबेटीको सम्बन्ध कायम भएकैले नेपालको आन्तरिक राजनीतिमा चीनकोभन्दा भारतको बढ़ी प्रभाव रहेको छ, (केरुंग, जेपी, २०७७४।२, गोरखापत्र दैनिक)। अनादिकालदेखि चलीआएको रोटीबेटीको सम्बन्धलाई हृदयड़म गर्दे स्थलमार्ग, जलमार्ग, हवाइमार्ग समेतको थप विस्तार गरी अभै नजिकिएर आर्थिक सहयोग तथा सांस्कृतिक आदानप्रदानलाई थप निरन्तरता र बढावा दिनुपछ। दक्षिण एसियामा विकसित राजनैतिक, भूराजनैतिक तथा सामरिक दृश्य तथा निरन्तर विस्तारित चीनियां प्रभावलाई मध्यनजर गर्दे अहिले भारतले छिमेकीसँग सम्बन्ध सुधार गर्न चाहेको देखिएको छ। (वाग्ले, गेजाशर्मा, २०७७७२६, कान्तिपुर दैनिक)। तसर्थ सीमासम्बन्धी समस्यालाई कूटनैतिक पहलमा आपसी बार्ताबाट समाधान गर्नुपछ र खुला सीमाको कारणले त्यसका आडमा दुबै देशमा हुनसक्ने आपराधिक गतिविधि हुन नदिन भारतसंगको सहकार्यमा सिमानामा तारबार लगाउने प्रवन्ध गर्नुपछ। 


\section{(ग) छिमेकी मित्रराष्ट्र चीनबाट लाभान्वित हुने}

छिमेकी मित्रराष्ट्र चीनले विगतका चारपाँच दशकभित्र गरेको अभूतपूर्व आर्थिक प्रगतिबाट हामीले पाठ सिक्नुपछ र चीनसँग सहकार्य गरी लाभान्वित हुनुपछ। चिनीयां राष्ट्रपति सि जिन पिडले सन् २०१५ मा ओबीओआर अर्थात 'एक पाटो एक बाटो' अर्थात ' वान बेल्ट एण्ड वान रोड' इनिसियटिवको घोषणा गरेका छन् र नेपाल पनि सन् २०१७ देखि त्यसमा आवद्ध भएको छ। यो विषयले मूलतः प्राचीनकालको रेशममार्गलाई आधुनिक ढड्रबाट पुनस्स्थापित र विस्तार गर्दे सामुद्रिक रेशममार्गका रुपमा स्तरवृद्धि गरी सिड्रो संसारसँग सम्बन्व, सम्पर्क, व्यापारिक आदानप्रदान, अन्तरकिया गरी विश्वभरिका सबै मानिसको समान साभा भविष्य निर्माण गर्ने लक्ष्य लिएको छ। 'बेल्ट' वा 'पाटो' भनेको एउटा क्षेत्र वा कम्तिमा दुईवटा देशलाई विकासको सहकार्य वा साभेदारीमा ल्याउने परियोजना हो भने 'एक बाटो' वा 'वान रोड' भनेको त्यसप्रकारले विकासको संयुक्त परियोजनामा गाँसिएका एउटा क्षेत्र वा समूहका देशहरूलाई जोड्ने यातायात सूत्रको रुपमा रहेको सहज सडक वा रेलमार्ग हो (सँग्रौला, २०७६, पृ. ६६१)। यसै क्रममा चीनले ओबीओआरकै प्राथमिक अवधारणालाई विकसित र उन्नत गर्ने ऋममा त्यसलाई नवीन स्वरुप दिई विकास साभेदारीको ढाँचाका रुपमा बीआरआई अर्थात् बेल्ट एण्ड रोड इनिसियटिवको अवधारणालाई अगाडि ल्याएको छ र यस अवधारणा अनुसार सडक तथा रेलमार्ग सन्जालबाट जनता, भूगोल, संस्कृति, बजार र उत्पादन क्षेत्रलाई जोडेर मानव विकासको समग्र संभावनालाई उजागर गर्ने अनि मानवीय क्षमताको प्रस्फुटन र एकीकरण गर्दे आर्थिक सामाजिक समृद्धिमा भमिका खेल्ने उत्प्रेरक तत्वहरूलाई सकृयता प्रदान गर्ने अभीष्ट राखिएको छ (सँग्रौला, २०७६, पॄ. ६६२)। चीनले निर्दिस्ट गरेका 'बी आर आई' सम्बन्धी $७$ बुँदाहरूमा शान्ति र सहिष्णुता निर्वाह गर्ने; असल छिमेकपन; एक अर्काप्रति विश्वास र निष्ठा; असल साभेदारको भावना; क्षेत्रीय सहयोग र सहकार्यको विस्तार; मित्रतापूर्ण राजनैतिक आर्थिक
र सांस्कृतिक सम्बन्ध र छिमेकीहरूलाई विकासमा सहयोग; र सर्वांगीण विकासको योजनासाथ व्यापार विज्ञान प्रविधि र वित्तीय क्षेत्रमा सहकार्य रहेका छन् (संग्रौला, २०७६, पृ. ७०९)। तसर्थ यो भनेको राजनैतिक वा भूसामरिक अभीष्ट नगाँसिएको नितान्त मानव विकाससँग सम्बन्धित विषय भएकाले नेपालले यसबाट भरपुर लाभ लिनसक्तुपई ।

\section{(घ) एमसीसी सम्भौताबाट लाभान्वित हुने}

अमेरिकाले एउटा रणनीति जारी गरेको छ जसको नाम इण्डोप्यासिफिक स्ट्राटेजी हो। यो रणनीति हिन्दप्रशान्त क्षेत्रका लोकतात्त्रिक देशहरूसँग अमेरिकाको सम्बन्व प्रगाढ बनाउंदै त्यहाँको आर्थिक उत्थान र गरिबी निवारण गर्न अनुदान प्रदान गर्ने विषयमा केन्द्रित छ। उक्त रणनीति अन्तरर्गत पर्ने देशहरूमा अमेरिकाले नेपाललाई पनि समावेश गरेको छ। सो रणनीति कार्यान्वयन गर्ने निकाय अमेरिकाको 'मिलेनियम च्यालेन्ज कर्पोरेसन' अर्थात 'एमसीसी' हो र नेपालले त्यसबाट लाभान्वित हुने ध्येयले 'एमसीसी' सम्कौतामा १४ सेप्टेम्बर २०१७ मा हस्ताक्षर गरिसकेको भए पनि त्यसलाई संसदबाट पारित गरिएपछि, मात्र कार्यान्वयनमा आउने भएको हुँदा सो प्रकिया बाँकी रहेको छ। सो सम्भौता लागू भयो भने नेपालमा अमेरिकी सेनाहरू आएर बस्छन् भन्ने हल्ला चलाइएको छ जुन सत्य होइन। नेपालमा सो परियोजना अन्तर्गत विद्युत सन्जाल र सडक सन्जालको व्यापक विस्तार गर्ने कार्यक्रम रहेको छ। परियोजनाबाट नेपाललाई पचास करोड अमेरिकी डलर अनुदान प्राप्त हुन्छ र यो रकम नेपाली मुद्रामा रुपान्तर गर्दा लगभग उनन्साठी अर्ब रुपैयां हुन आउँछ। एउटा गरिब मुलुकले विकास र समुन्नतिका लागि अर्को मित्रराष्ट्रबाट कुनै राजनैतिक वा भूसामरिक स्वार्थ नगाँसिएको परियोजना अन्तर्गत अनुदान सहयोग प्राप्त गर्नुलाई एउटा राम्रो अवसरको रुपमा लिनुपई र त्यसलाई यथाशीघ्र कार्यान्वयन गर्ने वातावरण सिर्जना गर्न गलत हल्लालाई चिर्दै राष्ट्रिय सहमतिको खोजी गरिनु आवश्यक छ। 


\section{सन्दर्भ सामग्री सूची}

अर्याल, ईश्वरराज (२०४३), नयाँ नेपालको इतिहास, काठमाडौं: रत्न पुस्तक भण्डार

उपाध्याय, उद्धवदेव समेत सं. (२०७०), आर्य खसका 94000 बर्ष, काठमाडौं: मधुवन प्रकाशन

केरुड, जी.पी. (२०७७/४/२), ओभेल पर्दे भारतीय भुमिका गोरखापत्र, पृ. ४ ।

खरेल, अश्वत्थामाभक्त (२०७६) राष्ट्रहितमा सामरिक महत्वको सान्दर्भिकता । युनिटी जर्नल अंक १, काठमाडौं: नेपाली सेना पृ. १६प्७००

खड्का, नवीन (२०७६६६६) सामाजिक सन्जाल युट्युब (इन्द्रेणी कार्यक्रमका सन्चालक कष्ण कंडेलले लोकगायक तथा संस्कृतिविद् नवीन खंड्कासँग लिएको भीडियो अन्तरवार्ता)

खड्का, श्याम बहादुर (२०७२) मस्टो संस्कृति र परम्परा, काठमाडौं: एकता बुक्स ।

गौतम, राजेश (२०४४ ४) दिव्यउपदेश, काठमाडौ: गोरखा समाज सेवा केन्द्र ।

थापा, शैलेन्द्र बहादुर (२०७६) राज्यको क्षमता अभिवृद्धिमा भूरणनीतिक सुरक्षा: अवसर र चुनौती। युनिटी जर्नल अंक १, प. २३३-३६

भण्डारी, ढुण्डिराज (२०२७) नेपालको आलोचनात्मक इतिहास, काठमाडौं: प्रकाश प्रकाशन

योगी, नरहरिनाथ (संम्वत) (२०७१) हिमवत्खण्ड, काठमाडौं:

नई प्रकाशन

लामा, महेन्द्र (२०७७/६/९) भारत, नेपाल अनि भविष्य कान्तिपुर पृ.६।

वाग्ले, गेजा, शर्मा (२०७७ कार्तिक २६) मोदीको सन्देश ओलीको सड्केत कान्तिपुर, पृ.७।
रेग्मी, जगदीशचन्द्र (२०३९) नेपालको ऐतिहासिक भूगोल, काठमाडौं: त्रिभुवन विश्वविद्यालय

शर्मा, भमकप्रसाद (२०७६) नेपालको सन्दर्भमा राष्ट्रियता र राष्ट्रिय एकता । युनिटी जर्नल अंक १, प् १७१-७६ शर्मा, बालचन्द्र (२०३३) नेपालको ऐतिहासिक रुपरेखा, वाराणसी: कृष्णकुमारी देवी

शर्मा, श्रीभद्र (२०४३३) मेची र महाकाली, कठठमाडौं:

श्रेष्ठ, बुद्धिनारायण (२०४७७) नेपालको सिमाना, काठमाडौ: भूमिचित्र नापनक्सा कम्पनी प्रा. लि.

श्रेष्ठ, हिरण्यलाल (२०३९) नयाँ नेपाल परिचय, काठमाडौं: नेसनल बुक सेन्टर

सिंह, तारिणीप्रसाद (२०२६) भारतको सिस्टमेटिक इतिहास, दरभड़ा विहार:

सँग्रौला, डा. युवराज (२०७६) दक्षिण एसिया चीन भूअर्थनीतिका आयामहरू, भक्तपुरः लेक्स इण्ड जुरिस पब्लिकेसन

Baniya, D. B. (2076). Geostrategic Importance of Nepal. Unity Journal, Vol.1, pp. 39-47

Cohen, S. (1973). Geography and Politics in a Divided World, New York: Oxford University Press.

Colin, D. (2013). Geopolitics Reborn, Foreign Policy Research Institute. Retrived from :https://www.fpri.org/docs/DueckGeopolitics_Reborn.pdf

Nehru, J. (1982). Glimpses of world history, New Delhi: Jawaharlal Nehru Memorial Fund 